\title{
Customer Relationship Management in Travel \& Tourism Industry
}

\section{Manjeet Singh}

\begin{abstract}
Customer relationship management (CRM) has once again gained prominence amongst academics and practitioners. However, there is a tremendous amount of confusion regarding its domain and meaning. In this paper, the main purpose was to study role of CRM in tourism sector. A CRM process framework is proposed for tourism companies. The data of this study were collected from literature, the internet and by using open interviews.
\end{abstract}

Key Words: travel agency, customer relationship management, service marketing mix, service quality, customer satisfaction, customer retention.

\section{1.Introduction}

CRM Defined According to Greenberg (2001), CRM is an enterprise-wide mindset, mantra, and set of process and policies that are designed to acquire, retain and service customer. CRM is not a technology, though technology is a CRM enabler (Greenberg, 2001, p.14). It is also a customer-focused business strategy which aims to increase customer satisfaction and customer loyalty by providing a more responsive and customized service to each customer (Fayerman, 2002). Many companies intend to build stronger relationship with their customers---called customer relationship management. CRM is defined as the process of managing detailed information about individual customer and knowing all customers "touching points" in order to maximize customer loyalty. A customer touch point is any occasion on which a customer encounters the brand and product from actual experience to personal or mass communications to casual observation. Companies then provide excellent real-time customer service by using and managing customers' individual account information effectively (Kotler and Keller, 2006, p. 152). For example, companies can provide customize market offerings, services, programs, messages, and media based on what they know about each valued customer. CRM is important for a company because the aggregate value of the company's customer base is a major driver of company profitability. (Kotler and Keller, 2006, p. 153)

\section{What is Customer Relationship Management (CRM)?}

Before we begin to examine the conceptual foundations of CRM, defining what CRM is would be useful. In the marketing literature the terms customer relationship management and relationship marketing are used interchangeably. As Nevin (1995) points out, these terms have been used to reflect a variety of themes and perspectives. Some of these themes offer a narrow functional marketing perspective while others offer a perspective that is broad and somewhat paradigmatic in approach and orientation. A narrow perspective of customer relationship management is database marketing emphasizing the promotional aspects of marketing linked to database efforts (Bickert, 1992). Another narrow, yet relevant, viewpoint is to consider CRM only as seeking customer retention by using a variety of after marketing tactics that lead to customer bonding or staying in touch with the customer after a sale is made (Vavra, 1992). A more popular approach with the recent application of information technology is to focus on individual or one-to-one relationships with customers that integrate database knowledge with a longterm customer retention and growth strategy (Peppers \& Rogers, 1993). Thus, Shani and Chalasani (1992) have defined relationship marketing as "an integrated effort to identify, maintain, and build up a network with individual consumers and to continuously strengthen the network for the mutual benefit of both sides, through interactive, individualized and valueadded contacts over a long period of time" (p. 44).

Jackson (1985) applies the individual account concept in industrial markets to suggest CRM to mean, "Marketing oriented toward strong, lasting relationships with individual accounts" (p. 2). In other business contexts, Doyle and Roth (1992), O’Neal (1989), and Paul (1988) have proposed similar views of customer relationship management. McKenna (1991) has professed a more strategic view by putting the customer first and shifting the role of marketing from manipulating the customer (telling and selling) to genuine involvement with the customer (communicating and sharing knowledge). Berry (1995), in somewhat broader terms, also has a strategic viewpoint concerned with CRM. He has stressed that attracting new customers should be viewed only as an intermediate step in the marketing process and that developing closer relationship with these customers and turning them into loyal ones should be equally important aspects of marketing. Thus, he proposed that relationship marketing be seen as "attracting, maintaining, and - in multi-service organizations - enhancing customer relationships" (p. 25). 
Berry's notion of customer relationship management resembles that of other scholars studying services marketing, such as Gronroos (1990), Gummesson (1987), and Levitt (1983). Although each one of them has espoused the value of interactions in marketing and its consequent impact on customer relationships, Gronroos and Gummesson take a broader perspective and advocate that relationships with customers be the focus and dominant paradigm of marketing. For example, Gronroos (1990) states: "Marketing is to establish, maintain, and enhance relationships with customers and other partners, at a profit, so that the objectives of the parties involved are met. This is achieved by a mutual exchange and fulfillment of promises" (p. 138). The implication of Gronroos' definition is that forming relationships with customers is the "raison de etre" of the firm and marketing should be devoted to building and enhancing such relationships. Similarly, Morgan and Hunt (1994) draw upon the distinction made between transactional exchanges and relational exchanges by Dwyer, Schurr, and Oh (1987) to suggest that relationship marketing "refers to all marketing activities directed toward establishing, developing, and maintaining successful relationships." The core theme of all CRM and relationship marketing perspectives is its focus on a cooperative and collaborative relationship between the firm and its customers, and/or other marketing actors. Dwyer, Schurr, and Oh (1987) have characterized such cooperative relationships as being interdependent and long-term orientated rather than being concerned with short-term discrete transactions. The long-term orientation is often emphasized because it is believed that marketing actors will not engage in opportunistic behavior if they have a long-term orientation and that such relationships will be anchored in mutual gains and cooperation (Ganesan, 1994).

Another important facet of CRM is "customer selectivity." As several research studies have shown, not all customers are equally profitable for an individual company (Storbacka, 2000). The company therefore must be selective in tailoring its program and marketing efforts by segmenting and selecting appropriate customers for individual marketing programs. In some cases, the "outsourcing of some customers" could be called for so that a company allocates its resources to those customers it can serve the best in order to create mutual value. However, the objective of a company is not really to prune its customer base but to identify the programs and methods that would be the most profitable as it creates value for the firm and the customer. Hence, our definition of CRM is that

Customer Relationship Management is a comprehensive strategy and process of acquiring, retaining, and partnering with selective customers to create superior value for the company and the customer. It involves the integration of marketing, sales, customer service, and the supply-chain functions of the organization to achieve greater efficiencies and effectiveness in delivering customer value.

As is implicit in the above definition, the purpose of CRM is to improve marketing productivity. Marketing productivity is achieved by increasing marketing efficiency and by enhancing marketing effectiveness (Sheth \& Sisodia, 1995). In CRM, marketing efficiency is achieved because cooperative and collaborative processes help in reducing transaction costs and overall development costs for the company. Two important processes of CRM include proactive customer business development and building partnering relationships with the most important customers. These lead to superior mutual value creation.

\section{CRM Objectives}

When an organization implementing CRM, there are various descriptions on the objectives for them, but the ultimate goal is to gain benefits. In this research, the authors will only discuss some selected ones which are important and relevant. According to Greenberg (2001), there are several objectives when organization implementing CRM:

1) Increase Revenue

2) Improve global forecast and pipeline management

3) Improve win probability

4) Reduce cost of sales

5) Increase sales representative productivity

6) Promote sales representative retention

According to Kim et al. (2003), it is more focusing on customer-oriented objectives. There are four categories: 1) Customer Knowledge, meaning that firms focus on gathering appropriate customer information, analyzing customer data, training employees, etc. in order to improve the quality of services they provide.

2) Customer Interaction, meaning that firms focus on the interactions with customers. For example, they provide quick and appropriate response to customer request, customizing products and services, etc.

3) Customer Value, for example, customer retention improvement, increase of customer profitability.

4) Customer Satisfaction, firms want to build long-term relationships with customers by improving the service quality. 


\section{Indentify customers}

Customers could be interested in either a relational or transactional contact with a firm. It may not always be a profitable for a firm to be relationship-oriented, because not all customers will be interested in forming relationship with service providers (Grönroos, 2007, p.37). So it is good for firms to identify their customers before forming relationships. On the other hand, it is difficult for a firm to satisfy everyone in a market because different customers have different preferences. Therefore, firms should identify and profile distinct groups of buyers who might require varying product and services. The marketers then decide their target market and target customers by evaluating which segments present the biggest opportunity (Kotler and Keller, 2006, p.24). 3.2.4 Customer database and database Marketing Marketers must know their customers. Companies must collect information of individual customers and store in a database and do database marketing in order to know the customers. A customer database is an organized collection of detail information about individual customers which is current, accessible, and actionable for marketing purposes such as providing good service, or maintaining long-term customer relationships. Database marketing is the process of building, maintaining, and using customer databases and other databases (products, suppliers, resellers) to contact, transact, and build customer relationships (Kotler and Keller, 2006, p.162)

\section{Customer satisfaction measurement}

Measuring customer satisfaction is a good way to know if customers received the same service with their expectations and it is an important factor in building customer relationship. Customer satisfaction is often measured by finding out the difference between service quality and customer satisfaction and a comparison of experiences with prior expectations (Grönroos, 2007, p.89). A number of methods exist to measure customer satisfaction. For example:

1) Periodic surveys. It is an easy way to track customer satisfaction directly. For customer satisfaction surveys, it is important that companies ask the right questions.

2) Customer loss rate can be monitored by companies. Companies contact customers who have stopped buying or who have switched to another supplier to learn why this happened.

3) In addition to tracking customer value expectations and satisfaction, companies need to monitor their competitors' performance in these areas (Kotler and Keller, 2006, p.146).

For customer-centered companies, customer satisfaction is both a goal and a marketing tool (Kotler and Keller, 2006), even though it may end up spending a lot of money for its implementation (Chi \& Gursoy, 2009).

\section{Customer Retention}

According to Gilbert (1996), he mentioned that nowadays companies should focus on the relationship marketing perspective rather than focusing on the traditional marketing which is defined as "the management process of identifying, anticipating and satisfying customer requirements profitably" (Gilbert, 1996, p.576). Grönroos (1991) assumes that marketing strategies have different characteristic which vary from transactional to relational marketing, and a relationship is usually long-term oriented.

\section{CRM and Travel \& Tourism Sector}

Globalization, increasing competition and advances in information and communication technology has forced companies to focus on managing customer relationships in order to efficiently maximize revenues (Ozgener, \& Iraz, 2006). In today's environment, firms are increasingly dependent on the relationship they have with their customers. With the implementation of customer relationships, firms often achieve greater payoff, such as positive word of mouth, referrals and loyalty (Kim \& Cha, 2002). In particular for service business, managing customer relationship is important because of the inherent intangibility and heterogeneous characteristics associated with service delivery (Cheng, Chen, and Chang, 2008). Customer Relationship Management (known as CRM) is defined as the process of managing detailed information about individual customers and developing stronger relationship with customers to maximize customer loyalty (Kotler and Keller, 2006, p.152).

Furthermore, CRM is considered as a key competitive strategy which companies need to focus on the needs of the customers and to integrate a customer-facing approach throughout the organization. (Ozgener, \& Iraz, 2006). Khalifa and Liu (2001) stated that, a survey of more than 1600 businesses and IT professionals which is conducted by Data Warehouse Institute, found that, some of the respondents have CRM project budgets of over $\$ 10$ million. By using information and communication technology, businesses are trying to get closer to customers so that they can create a long-term customer relationship. Thus, deploying CRM initiatives has become very common (Ozgener, \& Iraz, 2006). On the other hand, in the present age of economic globalization, tourism supplies and demands become one of the most exciting, progressive and one of the largest industries in the world (Jiang \& Cui, 2009). The World Tourism Organization (UNWTO) forecasts that international tourism will continue growing at the average annual rate of $4 \%$, expected to reach over 1.56 
billion by the year 2020. Of these worldwide arrivals in 2020,1.2 billion will be intraregional and 377 million will be long-haul travelers. Long-haul travels will grow slightly faster than intraregional travels and by 2020 its share will increase from $18 \%$ in 1995 to $24 \%$. By 2020, Europe will still be considered as the most popular destination, but its share will drop from $60 \%$ in 1995 to $46 \%$ (Long-term Prospects: Tourism 2020 Vision, World Tourism, 2004).

In its broadest sense, the tourism industry is the total of all businesses which directly provides goods or services to facilitate business, pleasure and leisure activities away from the home environment. Thus, tourism is a big business which has effects on almost every industry. It is said that nowadays tourism becomes everyone's business because everyone gains if travels are planned and managed in a proper way. Tourism brings significant benefits for regional areas by diversifying the area's economic base and expanding the employment market (Tourism, 2010).

\subsection{Problem Discussion}

\section{Theoritical Framework}

Referring to tourism, the role of travel agencies as intermediaries for distribution of airline reservations, ticketing, transactions (Vasudavan \& Standing, 1999) has changed. Since customers prefer travel agencies that can provide customized service, give expert advice on destinations, and assist in planning complex trips (Bureau of Labor Statistics, U.S. Department of Labor, 2007). A focus on customer relationships like providing customers value-added services, expert advice, and recommendations is becoming essential. Travel agencies provide invisible services to customers directly, and so customers are the most important and valuable intangible assets for them. Customers' satisfactions are much more important than the earnings of travel agencies. Therefore, compared with other organizations, travel agencies need to establish their own business idea which regards customers as centre, and improve their competitiveness by building and developing customer relationship (Jiang \& Cui, 2009). This is the reason why it is of interest to explore travel agencies and their use of CRM.

\subsection{Questions}

The research questions are formulated as follows:

How does Travel agency use Customer Relationship Management in their business?

What are the most important objectives for agency when they conduct customer relationship management?

\subsection{Purpose}

The purpose of this is to describe how agency uses customer relationship management.

\subsection{Target Group}

This is beneficial for travel agent, as well as tour operators, to evaluate their service and to find out the customer's expectation. It will also be of interest for other service companies who want to know how to keep customers' loyalty and satisfaction. Furthermore, it may be useful for students who want to conduct research which is associated to the customer relationship management.

\subsection{The Nature of Service}

Any performance or action that one party can offer to another that is essentially intangible is defined as a service (Kotler \& keller, 2006, p.402). Services are deeds, processes, and performances which include "all economic activities whose output is not a physical product or construction, is generally consumed at the time it is produced, and provides added value in forms (such as convenience, amusement, timeliness, comfort or health) that are essentially intangible concern of its first purchaser" (Grönroos, 2006, p.4).

\subsection{The Service Marketing Mix (The 7 P's)}

Marketing mix is one of the basic concepts in marketing which is defined as the elements an organization need to have in order to satisfy or communicate with customers. The four Ps (product, price, place and promotion) is used in the traditional marketing mix. These four elements are considered as main variables in any marketing plans. All of those variables, to some extent, are interrelated and depend on each other (Zeithaml et al., 2006, p.25).

According to Zeithaml (2006), service is usually produced and consumed simultaneously, so customers sometimes have to interact with the service firms directly which is considered as a process of the service production. Besides, in order to understand the nature of the service experience, customers always have to look for physical cues. The awareness of the importance of these additional variables has led service marketers to adopt the concept of an expanded marketing mix for services, including people, physical evidence and process (Zeithaml et al., 2006, pp.25, 26). 
All of the marketing mix elements may affect the consumer's initial purchase decision, the customer's satisfaction level and repurchase decisions (Zeithaml et al., 2006, p.27). On the other hand, devising marketing activities and programs to create, communicate, and deliver value for consumers are the main tasks for almost all the marketers (Kolter \& Keller, 2006, p.19).

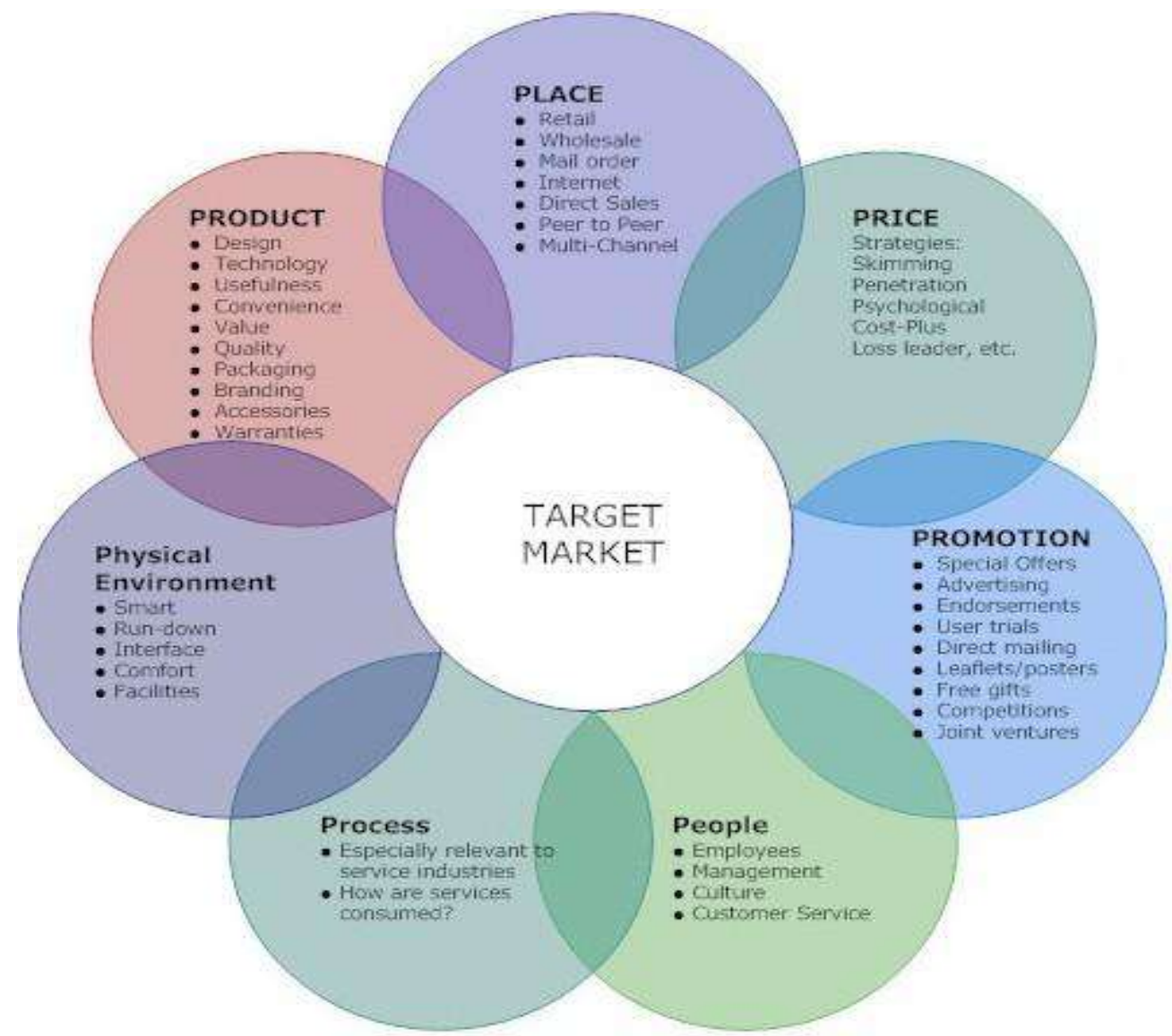

Figure : Expanded Marketing Mix for Services

8.6.1.Product: It could be a physical product or an intangible service. Referring to tangible products, some characteristics are mentioned as shown in the figure, namely, the product variety, quality, design, features, branding, packaging, warranties etc.

8.6.2.Place: It is the place where products can be sold, and associated with channels of distribution in order to offer products to target customers. There are a lot of different channels, for example, retail, wholesale, mail order, internet etc.

8.6.3.Price: Price is the amount of money which customers pay for the product. There are different strategies to make pricing decisions, like cost-plus, penetration, so pricing includes not only list price, but also discounts, allowance, and so on.

8.6.4.Promotion: In order to sell products and to draw attention from customers, marketers use any different kinds of communication tools to do promotion, like advertising, public relations, special offers, free gifts etc (Inspired by Figure2).

8.6.5.People: All human actors who involve in the process of service delivery and their actions could influence buyer's perceptions. For example, the firm's personnel, the consumers are people in the process of service. (Zeithaml et al., 2006, p.26)

8.6.6.Physical evidence: The environment where the service is delivered, where the firm and customer interact and contact with each other. Tangible components that facilitate performance or communication of the service could be considered as physical evidence as well (Zeithaml et al., 2006, p.26-27). 
8.6.7.Process: It is the actual procedures and flows of activities by which the service is delivered, namely, the service delivery and operating systems. (Zeithaml et al., 2006, p.26-27).

\section{Service Quality}

In regard to Zeithaml (2006), research suggests that customers' percepetion of quality is based on multiple factors relevant to the context. The dimensions of service quality have been identified through the researches. (Zeithaml et al., 2006, p.116). These five determinants (shown in Figure ) characterize customers' perception of the service. (Grönroos, 2007, p.84)

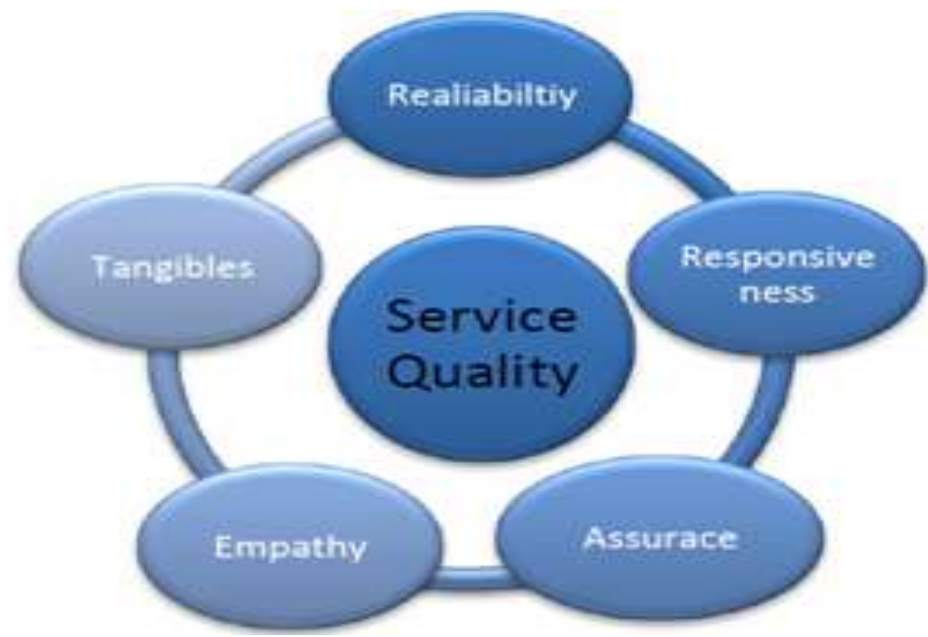

Figure 4: The five dimensions of service quality (Inspired by Grönroos)

These dimensions, as drivers of service quality, explain how consumers organize information delivered to them in their minds.

\subsection{Reliability: Delivering on promises}

Reliability has been considered to be the most important to the perceptions of service quality of the five dimensions. It is defined as the ability to perform the promised service dependably and accurately. Customers always would like to do business with companies that keep their promises and core service attributes. (Zeithaml et al., 2006, p.116)

\subsection{Responsiveness: Being willing to help}

Responsiveness is the willingness to help customers and to provide good service. This demension means that firms should be attentiveness and promptness in dealing with customer questions, complaints, and problems. Customers may evaluate responsiveness of a firm by the length of time they have to wait for assistance, answer questions, or attention to their problems. Responsiveness captures the notion of flexibility and ability of a firm to customize the service according to customer needs. (Zeithaml et al., 2006, p.117)

\subsection{Assurance: Inspiring trust and confidence}

Assurance is the ability of the firm and its employees' knowledge and courtesy to inspire trust and confidence. This dimension plays a particularly important role in the services that customers perceive as high risk or for services which they feel uncertain about firms' ability to evaluate outcomes. (Zeithaml et al., 2006, p.118)

\subsection{Empathy: Treating customers as individuals}

Empathy is the caring, individualized attention and customized service that the firm provides to its customers. The essence of empathy is providing personalized or customized service to make customers feel that they are unique, special and that their needs are understood. (Zeithaml et al., 2006, p.119)

9.5.Tangibles: Representing the service physically

Tangibles are the appearance of physical facilities, equipments, personnel, and communication materials. Tangibles provide physical images of the service that customers, particularly new customers, will use to evaluate quality (Zeithaml et al., 2006, p.117). 


\section{Conclusion}

Study supports the original thought that CRM is diversely needed and maintained in tourism sector. It also shows that it has been possible to stabilize CRM both in operating area among competitors as well as among consciousness of customers.

Major importance of CRM is an explicit division of its areas that are applied to reach the most profit through the most suitable method. These various methods can be used for improving the operations to manage the challenges that tourism and travel sector meets.

\section{References}

[1]. Bureau of Labor Statistics, U.S. Department of Labor. (2007). Occupational Outlook Handbook, 2008-2009 Edition. Travel Agents. Retrieved November 4, 2009 from ad-dress: http://www.bls.gov/oco/ocos124.htm.

[2]. Chi, C. G., \& Gursoy, D. (2009), "Employee satisfaction, customer satisfaction, and financial performance: An empirical examination", International Journal of Hospitality Management, Volume 28, pp. 245-253

[3]. Christian Grönroos, <<Service Management and Marketing: Customer Management in Service Competition >>, 3rd Edition, John Wiley \& Sons Ltd., 2007.

[4]. Claycomb, C., \& Martin, C. L. (2002), "Building Customer Relationship: An Inventory of Service Providers' Objectives and Practices", Journal of Service Marketing, 16(7), Pages 615-635.

[5]. Cui Zhenxing and Jiang Hua, Study on Tourism CRM Based on Fuzzy Evaluation/ Journal of 2009 Sixth International Conference on Fuzzy Systems and Knowledge Discovery, Volume 6, 2009, page 428-431

[6]. Clarke, A.Tourism Management: Analysis, Behaviour and Strategy, Tourism Management, Volume 31, Issue 1, Year 2010 Pages 148--149

[7]. David Gilbert and Robin K. C. Wong/Tourism Management, Volume 24, Issue 5, October 2003, Pages 519-532

[8]. E. Arnould, L. Price and G. Zinkhan, <<Consumers >>, 2nd Edition, McGrw-Hill, New York.

[9]. Eric Laws, <<Tourism Marketing: Quality and Service Management Perspectives>>, Continum, 2002.

[10]. Fayerman, M., (2002), Customer Relationship Management. New Directions for Institutional Research, Vol.1, No.112, pp. 57-67.

[11]. Driggs Woody, Your customers want you to know them/ Journal of customer relationship management, Volume: 13, issue4, 2009, page 14.

[12]. Eric Pels, Research in Transportation Economics/ The Economics of Low Cost Airlines, Volume 24, Issue 1, 2008, Pages 68-74

[13]. Fisher, C. (2007). Researching and writing a dissertation, a guidebook for business students. EssexEngland: Prentice Hall, p. 5, pp.31-33.

[14]. Goldenberg Barton, Assessing your CRM situation/Journal of customer relationship management, Volume14, Issue1, 2010, page10

[15]. Gefen, D. \& Ridings, C. M., (2002), Implementation team responsiveness and user evaluation of customer relationship management: A quasi-experimental design study of social exchange theory. Journal of Management Information system, Vol.19, No.1, pp.47-69.

[16]. Ghauri, P., Gronhaug, K., (2005), <<Research Methods in Business Studies: A Practical Guide >>, 3rd. Edition, Prentice-Hall, Financial Time, London, England.

[17]. Greenberg, P. (2001), CRM at the Speed of Light: Capturing and Keeping Customers in Internet Real Time. Berkeley: Osborne/McGraw-Hill.

[18]. Gummesson, E., Internal Marketing in the light of relationship marketing and virtual organizations. In Lewis, B. \& Varey, R. (eds), Internal Marketing. London: Routledge, 2000.

[19]. Gursoy, D., Swanger, N., (2007), “Performance-enhancing internal strategic factors: impacts on financial success". International Journal of Hospitality Management, Vol. 26, No.1, Pages 213-227

[20]. Heskett, J. L., Jones, T. O., Loveman, G. W., Sasser, W. E., Schlesinger, L. A., (1994), "Putting the service-profit chain to work", Harvard Business Review, Vol.72, No.2, pp.164-175.

[21]. Jao-Hong Cheng, Fang-Yuan Chen, and Yu-Hern Chang, Tourism Management, Volume 29, Issue 3, June 2008, pp. 487-499.

[22]. Kim, J., Suh, E. \& Hwang, H. (2003), A Model of Evaluating the Effectiveness of CRM using the Balanced Scorecard. Journal of Interactive Marketing. Vol.17, No.2, p. 5-19.

[23]. Kim, W., G., \& Cha, Y., “Antecedents and consequences of relationship quality in hotel industry", International Journal of Hospitality Management, Volume 21, 2002, Pages 321-338

[24]. Lundahl, U., \& Skärvad, P-H. (1999). Utredningsmetodik för samhällsvetare och

[25]. ekonomer. Lund: Studentlitteratur.

[26]. Musico Christopher, Hold onto your customers! / Journal of customer relationship management, Volume:13, Issue:2, 2009, Pages $30-35$

[27]. Ozgener, S.; Iraz, R., "Customer relationship management in small-medium enterprises: The case of Turkish tourism industry", Tourism Management, Volume 27, Issue 6,Year 2006, Pages 1356-1363

[28]. Philp Kotler, Kevin Lane Keller, <<Marketing Management>>, 12th.edition, Pearson Prentice Hall, cop. 2006

[29]. Powney, J., Watts, M. (1987), Interviewing in Educational Research. London: Taylor \& Francis.

[30]. Saunders, M., Lewis, P., Thornhill, A. (2007), <<Research Methods for Business Students >>, 4th. Edition, Prentice Hall, Harlow.

[31]. Richard L. Oliver, Satisfaction: A behavioral Perspective on the Consumer, New York, McGraw-Hill, 1997.

[32]. Reyes-Garcia, V., Godoy, V. V. R., Byron, E., Huanca, T., \& Leonard, W. R. (2005). Interviewer Bias: Lessons from Panel and Cross-Sectional Surveys from a Native Ama-zonian Society. Tsiamane'Amazonian Panel Study Working Paper, 15.

[33]. Robert K. Yin, <<Case Study Research: design and methods〉>, Applied Social Research Methods Series, Volume 5, 3rd.Edition. Thousand Oaks, California: Sage Publications, Inc.

[34]. Stockdale Rosemary, Managing customer relationships in the self-service environment of e-tourism, Journal of Vacation Marketing, Volume 13, Issue 3, Year 2007, Pages 205--219

[35]. UNWTO World Tourism Barometer (World Tourism Organization) Volume 7.No 2.June 2009

[36]. Urban, "The Emerging Era of Customer Advocacy," pp. 77-82

[37]. Valarie A. Zeithaml, <<Service Marketing-Integrating Customer Focus Across the Firm >>, 5th. Edition, McGraw-Hill/Irwin, 2009, p. 28

[38]. Vasudavan, T., \& Standing, C. (1999). The Impact of the Internet on the Role of Travel Consultants. Participation and Empowerment: An International Journal, (7)8, 213-226. 